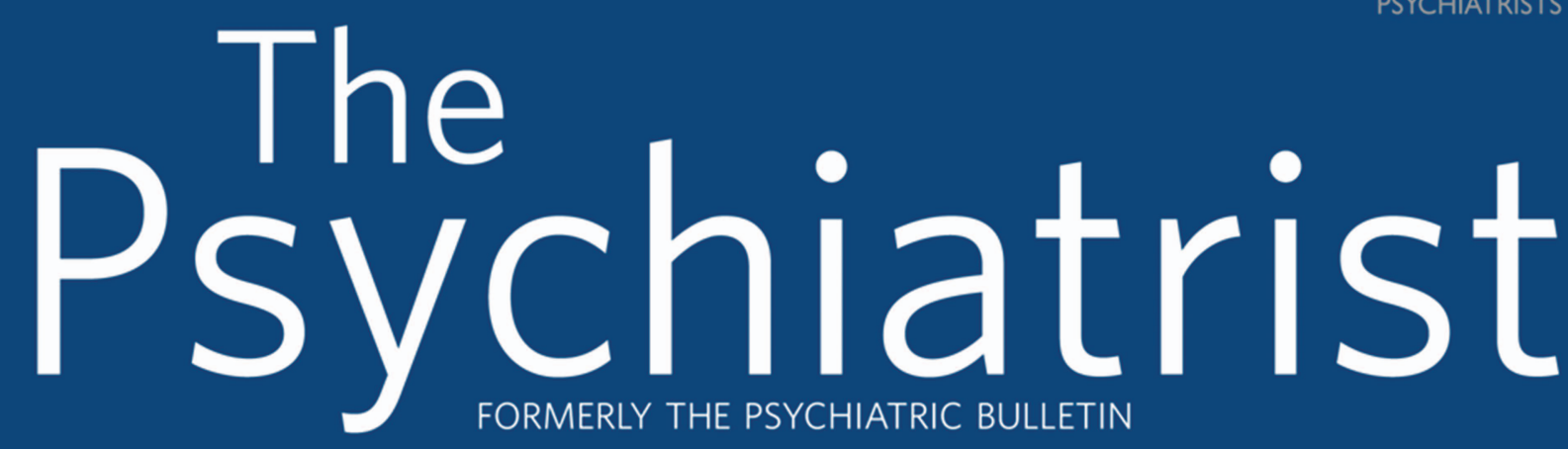

Smoke-free . : .

\title{
and secure
}

